\title{
Reinterpretation of Pracimayasa Building in Pura Mangkunegaran Surakarta: An Attempt of Conserving Local Wisdom
}

\author{
$1^{\text {st }}$ Sunarmi
}

Doctorate Program in Cultural

Studies Universitas Sebelas Maret of Surakarta

Surakarta, Indonesia

narmied@yahoo.co.id $2^{\text {nd }}$ Bani Sudardi

Professor in Cultural Studies

Major Universitas Sebelas Maret of Surakarta

Surakarta, Indonesia

banisudardi@yahoo.co.id

$4^{\text {th }}$ Titis Srimuda Pitana

Associate Professor in Cultural Studies Universitas Sebelas Maret of Surakarta

Surakarta, Indonesia

titis_pitana@yahoo.com

\author{
$3^{\text {rd }}$ Pande Made Sukerta \\ Professor in Cultural Studies \\ Major Universitas Sebelas Maret \\ of Surakarta \\ Surakarta, Indonesia \\ pandemadesukerta@gmail.com
}

\begin{abstract}
T The change of Pracimayasa building's function into cultural tourist space in dinner tour form conceived as the reinterpretation of cultural pledge for conservation purpose. It is noteworthy that the truth is not singular and not only determined by mind and rationality. For that reason, the following problems should be addressed: (1) how is the reinterpretation of Pracimayasa building in dinner tour package, and (2) how is the local cultural resilience of Pradicamayasa building in dinner tour. This study employed critical approach with deconstruction theory supported with visual communication semiotic theory. This study was expected to provide the opportunity of developing creativity in interpreting text, in this case cultural pledge building. Data collection was carried out using observation, interview, and document and library study. Data validation was conducted using data triangulation. The result of research showed that (1) the reinterpretation of Pracimayasa building positioned Pracimayasa building formerly serving as Mangkunegaran family's residence to be branding of dinner tour in the framework of enlivening royal guest welcoming tradition, and (2) viewed from the local cultural resilience, all interior elements and the interior element layout of Pracimayasa building can be maintained its sustainability visually, but the meaning of interior shifts from the private to profit one, reinforcing consumerism culture. Therefore, the reinterpretation of Pracimayasa building still has an opportunity of reinterpreting and reconstructing the conservation of Pracimayasa building currently becoming dinner tour package in Pura Mangkunegaran leading to instilling character education heritage, inculcating character education about the nation's self identity.
\end{abstract}

Keywords- reinterpretation, dinner tour, Pracimayasa

\section{INTRODUCTION}

Begining from the year of 1989, Pracimayasa building located in Pura Mangkunegaran of Surakarta has been a cultural tour package in Gala Dinner label or Mandrapura office called it Dinner Tour in Pura Mangkunegaran. This package offers the ala-Mangkunegaran beautiful banquet in Pracimayasa building. The intense diffusion of information on beautiful dinner tour in Pracimayasa building in cyberspace puts Pracimayasa building to be commodity affordable to everyone. The building is considered a high-value artworks from the former Duchy of Mangkunegaran is evidence of the local lifestyle [14]. The uniqueness of architectural forms, spaces, and elements of interior Pracimayasa rated on par with some of the other buildings, including pendapa in Mangkunegaran Surakarta nor as the representative of the style of the interior of Java.

Pracimayasa building mainly refers to a residence of Pura Mangkunegaran or Javanese royal family and the symbolic reference for glory and the Mangkunegaran noble lifestyle. This building consists of several spaces which shows a manifestation of the cultural works result reflecting values, prerequisites, ideology, truth, and goals in this case is interpreted as a text. This is as suggested by Pitana [9] that architecture is a text of source values, prerequisites, ideology, the truth, and purpose. If the building consists of several spaces as a text of culture 
then it should be properly read to be able to unveil the residing meanings. Thus, critical study on commodification of Pracimayasa building holistically needs to be undertaken, since it is oriented to bridging out understanding of how the produced meanings in capitalist worlds remains contradicted, and how are implications of Pracimayasa building commodification carried out in Pura Mangkunegaran and specific impacts towards the socio-cultural life of Mangkunegaran court, supporting society, and physical form of the interior itself.

This study used critical approach of Deconstruction and Semiotic Visual Communication theories. . Deconstruction is not a simple dismantling of unloading things, but is re-unraveling what has happened, to seek new meaning among the cracks of the text by means of delays at the prior meanings. Several studies have previously addressed this issue. Ramzy's visual language analysis on Mamluk architecture [10] revealed siginificant messages embodied in the building, the message varries from functional to technical. The use of semiotic reading has been optimally used to reveal spiritual message towards the building. Marrota et al. [7] typologically highlight visual image and language in architecture, the study further explored on the method of visual communication and linguistics to explain Islamic architectural building, who asserted that the Islamic building concerns about colors and symetrical case, one shape relates to the other and engage the signification and signifier. In addition to that, Benoit (2016) elabrated the reasons underlying the use of visual communication from philosophical understanding. Above all, among the previous studies have not yet studied both architectural and semiotic phenomena from the perspective of cultural studies.

The change of Pracimayasa building's function into dinner tour package should be conceived as the form of Pracimayasa building reinterpretation by Mangkunegaran in repositioning Pracimayasa building in current global era. As mandated by RI's Law No.11 of 2010, IN Chapter 1, No. 22, conservation is a dynamic attempt of maintaining Cultural Pledge and its values by means of protecting, developing, and utilizing it. On the other hand, making Pracimayasa building a dinner tour package is not the only conservation measure. The truth is distributed along human experience, not only determined by mind and rationality. In this context, it is important and remains relevant to address the concept of conserving Pracimayasa building currently becoming dinner tour package from local wisdom conservation aspect. For that reason, the following problems should be addressed: (1) how is the reinterpretation of Pracimayasa building in dinner tour package, and (2) how is the local cultural resilience of Pradicamayasa building in dinner tour. This study is expected to give everyone the awareness of caring about cultural pledge and the opportunity of developing creativity in interpreting text thereby acquiring an understanding on dinner tour in Pracimayasa building, viewed from local culture resilience.

\section{METHOD}

A study on the reinterpretation of Pracimayasa building is the one included into cultural studies studying dinner tour phenomenon in Pracimayasa building of Pura Mangkunegaran Surakarta, viewed from local wisdom aspect. This research was conducted in critical thinking system, in which dinner and lunch tour phenomenon in Pracimayasa building is positioned to be a readable text thereby the meaning lay behind becomes understandable. It is a study attempting to read meaning, thus, the data was descriptive in nature. Therefore, this study is under the research paradigm of descriptive-qualitative analysis technique.

This study used critical approach of Deconstruction and Semiotic Visual Communication theories. Deconstruction is not only a simple attempt of deconstructing, but re-elaborating anything that has occurred to search for new interpretation between the figures of text by means of postponing the previous meaning. Those signs become free signs, free words, and language interpreted freely and automatically, generating varying and plural meaning [6]. According to Semiotic Visual Communication theory, semiotic process occurs in sign interpretation. Semiotic process results in a series of endless relation, an interpretant will be representament, be interpretant and representament again adifinitium. Such movement is called borderless vicious semiotic process [15], [2].

The data was taken from 2015 to 2018 by using the technique of observation and in-depth interviews supported with document and library studies. The data were obtained from selected informants consisting of stakeholders that allows the commodification and constituent concepts, distributional process, commodity producer-actors of Pracimayasa building which has been practically packaged into a tourism guideline The secondary data source was obtained from book, journal, document, and finding of previous studies related to customary activities and etiquette in Mangkunegaran..

\section{RESULTS AND DISCUSSION}

On the Republic of Indonesia's independence era, Pracimayasa building becomes a cultural pledge. The attempt taken by Mangkunegaran to conserve that it is to reinterpret the meaning of Pracimayasa building in order to maintain sustainability in global era. The reinterpretation of Pracimayasa building positions Pracimayasa building as the one in Pura Mangkunegaran Surakarta. In the concept of spatial layout of Javanese traditional house, Pracimayasa is a building supporting the main building: pendapa, paringgitan, and dalem ageng. It can be seen from 
Pracimayasa building located in gandhok tengen (right kitchen) rather than in the main building.

In the Javanese traditional house, every room reflects different values, divided into three areas: from the front to the back, showing the characteristics of a room from public to private ones. The front part is an outside-oriented area where domestic prestige and social regularity are featured in the form of different status and formality (Santosa, 2000:211). Status and formality of Mangkunegaran building shape as the former kadipaten or house for princes (kepangeranan) are generally assessed from the shape and layout of pendapa, paringgitan, and dalem ageng buildings.

This is not to say that the position of Pracimayasa building in gandhok area has no important position. In modernity era, the position of Pracimayasa serves important position in Mangkunegaran. This is as Job Ave [3] explains that in the central part of Pura Mangkunegaran, exactly behind dalem ageng, there is Mangkunegaran family's residence that still has a quiet circumstance like rural houses, Pracimayasa building. The statement was deliberately presented in lux-edition book and his position as Tourism minister supported the tourism development in Mangkunegaran. Pracimayasa building's appeal as Mangkunegaran family residence becomes branding to develop cultural tour in Mangkunegaran in the form of dinner tour.

Supriyanto explains,

"dinner tour is a tour package treating tourist just like royal guest. As royal guest, tourist is treated and served by Mangkunegaran specially, just like royal guest in Pura Mangkunegaran" (interview on March 4, 2015).

Considering the citation above, it can be seen that the dinner tour package sells building circumstance like the place of welcoming Mangkunegaran Royal Guest. The word like (Indonesian, layaknya) in online Indonesian Dictionary can be defined as should be (https:// www.apaarti.com/layaknya.html, download on January 5, 2018 at 03.23 p.m.). The word layaknya is defined as just like, meaning not actually occurring, what occurs is only like the reality or simulation.

Term simulation or simulakra is used in this study to be an appearance production model of Pracimayasa building reinterpretation. Baudrillard said that simulacra is no longer related to duplication of being or substance of something duplicated, but the creation through real models of something without origin or reality, so called hyper-real [8]. The reference of duplication is not merely reality, but also unreality or fantasy. The sign of royal guest welcoming is produced, fantasy of guest welcoming ceremony is simulated to be the as if-real one, and building and interior layouts of Pracimayasa building are presented as if to welcome the royal guest.
In that context, Pracimayasa building is not simulacra but the simulacra is the coming guest/tourist. It is noteworthy that simulacrum process encourages the advent of term hyper-reality, in which there is no longer the more real one, because the reality no longer becomes a reference. Baudrillard considered simulation and hyper-reality era as a part of a series of successive branding phases including: (1) reflecting reality, (2) concealing or misleading the reality, (3) concealing the absence in the reality, (4) showing the absence of relation between any reality and it is purely simulacrum/imitation [11]. Simulation is basically an attempt of presenting the reality of certain representation constructed through sign. The sign constructed is simulacrum of royal guest welcoming in Pracimayasa building for dinner tour as elaborated below.

Having welcomed in topengan and pendapa of Mangkunegaran, tourists then attend dinner tour banquet in Pracimayasa dining room (see figure below).

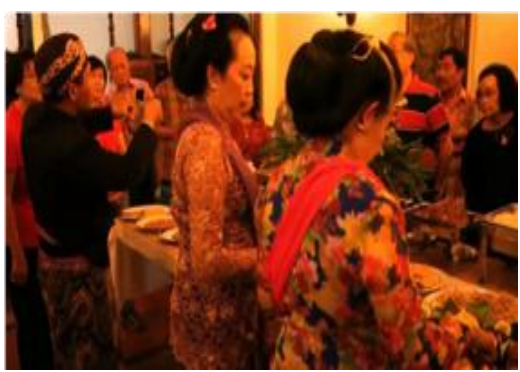

Figure 1. Pracimayasa Dining Room as the Banquet Ceremony Place

(Sunarmi, March 25, 2015)

All elements and interior element layout of dining room and Pracimayasa ward are featured as the reality of Istana Mangkunegaran banquet interior circumstance. The room is arranged just like the layout of Pracimayasa dining room chair, and nothing is modified (see figure below).

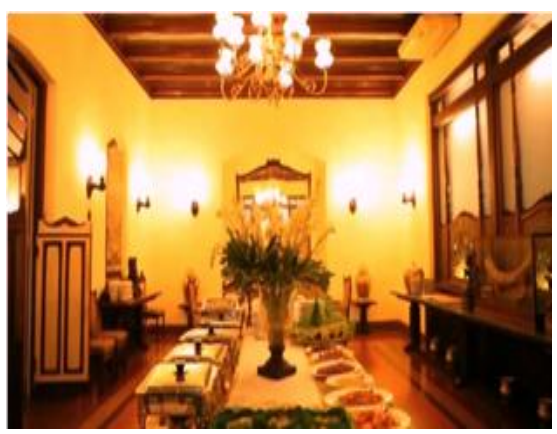

Figure 2. Pracimayasa Dining Room as the Dinner Tour Banquet Place

(Sunarmi, March 25, 2015)

Gamar explains that: 
“... all interior elements of Pracimayasa, either in dining room or in the ward, have never been modified and are always maintained in dinner tour or lunch, to present the actual circumstance" (interview, on August 25, 2015).

Having attended the dinner opening ceremony in dining room, tourists can choose their seat for having meal in the dining room or in Bangsal Pracimayasa (Pracimayasa Ward) freely. Kuntawijaya explains that as the form of respect, there is language hierarchy in Java [4]. Language hierarchy is used to shows the presence of levels or positions. It can be seen from the name of Pracimayasa living room called bangsal commonly intended to the respected ones. The principle of hierarchy can also be seen from the furniture layout in Bangsal Pracimayasa.

The layout of seats in bangsal Pracimayasa follows symmetrical order in hierarchy principle. The shape and layout of seats in bangsal Pracimayasa guides people to enter into paugeran (regulation) about respect to different position and status. Seat shape and its number (6) arranged in the front facing outside presuppose that the seats are intended to elders or because their position as the owner of house. Hierarchical structure indicates the recognition of basic norms of intercourse pattern in Javanese people's life. Hildred Geertz explained that, there are two basic norms of intercourse pattern in Javanese people. Firstly, in every situation, Javanese people behave in such a way that does not result in conflict, called the principle of concord. Secondly, human beings in their way of speaking and behaving always show respect to others according to their degree and position, called the principle of respect [13]. Interior of bangsal Pracimayasa is designed as a place of welcoming guest. The shape and layout of furniture builds on the principles of concord and respect positioning the people according to their position. The difference of strata is governed clearly by a real dichotomy through seat shape and layout indicating the different allocation and place between the elder (sepuh) and the youth (nem). Main seats are prepared for the elders and supporting seats for the youths arranged in such a way that is like a hierarchical order.

In bangsal Pracimayasa, there is a partition (warana) to conceal (aling-aling) the door of bangsal Pracimayasa connected to the room with privacy symbol. To Javanese people, warana is the furniture that should be owned as the part of interior element of Javanese traditional house [12]. Warana is not only a part of privacy symbol but also the identity symbol of a room pertaining to ownership and the symbol of glory. It can be seen from the logo of partition (warana) and the photographs of KGPAA Mangkunegaran VIII and his wife on the left and KGPAA Mangkunegaran XI on the right (see figure below).

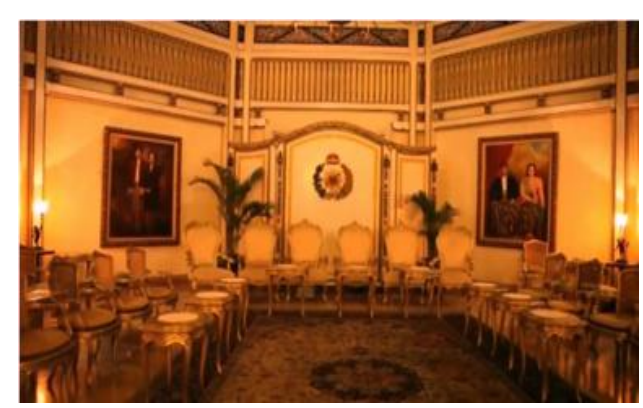

Figure 3. Furniture Layout in Bangsal Pracimayasa during Dinner Tour

(Sunarmi, March 25, 2015)

This room grandiosity is indicated with its opened shape connected directly to the opened nature connecting patiop bale warni and bale peni. Rural circumstance is created because the yard outside the ward is completed with park containing such domesticated animals like antelopes, birds, and chicken.

During dinner tour, a series of activities is arranged based on idea of establishing a royal guest welcoming circumstance. The sign production of royal guest welcoming is sent or received and enjoyed by dinner tourists to deliver hyper-reality of royal guest. The sign constructed into a text, according to semiotic theory, can be considered as encouraging the visual communication relation. As Urgo Eco suggests, the work mechanism of semiotics in visual communication, in this case the organizer of Pracimayasa building becoming the producer of commodity or called interpretant of the first sign to be built (Pracimayasa building), in turn refers to the object (meaning of Pracimayasa building), while abdi dalem represents or becomes representament during diner tour, and then tourists catch (receive) and enjoys the packager, called representament. Thus, a sign or representament has triadic relation with interpretant and object. However, in turn, the message of meaning to be delivered by producer can be interpreted differently by consumers, in this case, tourists, because they have different ideology.

Tourist behavior can be observed when they are in Bangsal Pracimayasa during dinner or lunch tour as shown in figure 4 . The function of Bangsal Pracimayasa shifts into socialite place. One of groups governs its members to take picture in Bangsal Pracimayasa in turn. Some others attempt to document moment in Bangsal Pracimayasa using cellular phone. In daily activity, the interior circumstance serves as wingit place meaning that not everyone is feasible to occupy it when there is no calling (timbalan) from Pura Mangkunegaran, but during dinner tour it becomes photo booth. 


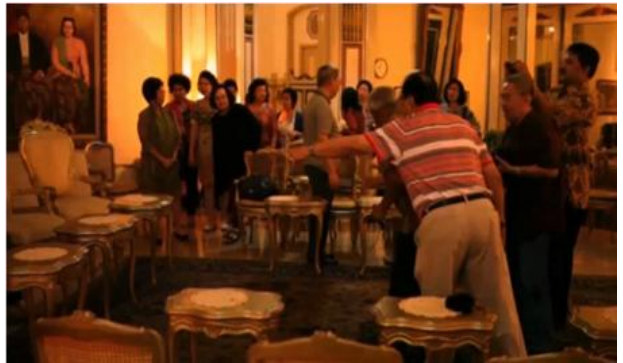

Figure 4. Tourists take photograph in turn in front of Warana in Bangsal Pracimayasa

(Sunarmi, March 25, 2015)

Tourists sat the six seats (chairs) that should be those for the host, see figure below.

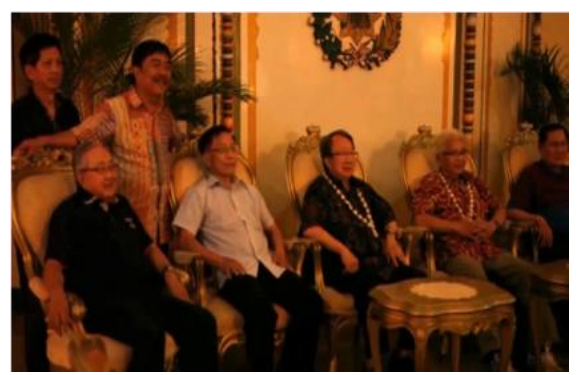

Figure 5. Six Chairs in front of Warana in Bangsal Pracimayasa becoming Photo Booth

(Sunarmi, March 25, 2015)

The figure above shows that the reinterpretation of Pracimayasa building that is intended to enliven Pracimayasa building tradition as the family residence is finally caught by tourists in hyper-reality as the socialite place. Facing the change, the reinterpretation of Pracimayasa building Mangkunegaran positions Pracimayasa building to be an object or commodity of traditional enlivening. Tourists as consumers do this to meet their need. Such need is created by consumption object because object act as the object category determining human category arbitrarily.

Banquet moment in bangsal Pracimayasa becomes valuable memory, as a commodity to enter cyberspace for tourists, travel agent, and guide through viral social media. The dissemination of memorial tour photographs in Pracimayasa building can lead the community to be consumers. Meanwhile, to tourists, it is the attempt of constructing a sign about themselves leading to exclusivity. The phenomenon will have sustainable effect because the effect of social media and technology can create broader consumerism culture.

Similarly, Adian [1] says that the advance of social media and technology indirectly leads to creating consumer community, and object marks social status and replaces any difference of social hierarchy existing. Community can perceive an introduction of universal code as an indication that people that can get dinner or lunch banquet opportunities in bangsal Pracimayasa along with various facilities have high and peculiar social status because not everyone can get it. Cultural tour putting Pracimayasa building as dinner or lunch tour destination makes the consumptive community creation room broader; as a result, consumption in this perspective can determine an individual's social status. In capitalist system, human relation has been transformed into object relation controlled with certain code and sign [11]. Human status tends to be measured based on consumed sign. Different status is interpreted as different sign consumption, and wealth is measured from the number of signs consumed.

Dinner or lunch tour phenomenon is analogized with screen and network changing Pracimayasa room into a public consumption space through simulacrum of royal guest welcoming. In the next stage, simulacrum in commodification of Pracimayasa building in Mangkunegaran contains various dramatizations made through a plot replete with dramatic action. Simulacrum of royal guest welcoming place interior in Mangkunegaran occurs due to the community's trust in the reality that is actually unreal. This reality tricking will result in a cultural pattern easily imitating what has been viewed as a reality realized into the organization of Mangkunegaran Royal Guest banquet. Therefore, such modification will make Mangkunegaran patterned to be consumptive community articulated as the community created and supported by consumption as its livelihood, making consumption the life activity center with the wish to always and always consume [5]. Thus, Pracimayasa building conservation by means of developing dinner package is not more than a need-oriented object with exchange value. The exchange value of Pracimayasa building leads to the temporary fulfillment of need for prestigious value. Tour prestige place becomes photo booth filling in social media reinforces consumerism culture rather than conserve royal guest welcoming tradition.

\section{CONCLUSION}

The reinterpretation of Pracimayasa building is to interpret Pracimayasa building formerly serving as the residence of Mangkunegaran family to be an object of enlivening royal guest welcoming tradition in dinner tour package. Dinner tour package creates a pattern of royal guest welcoming simulation. All of interior elements and layout of interior elements in Pracimayasa building are maintained to build a circumstance about the interior of royal family residence in welcoming guest. Viewed from visual aspect, it can be said that the interior Pracimayasa can be maintained for its sustainability.

However there is a shift of meaning. The meaning of Pracimayasa building sign as private place, where etiquette lives is in turn perceived with different meaning by tourist. A series of codes is constructed to represent the content, but in communication process, text is interpreted in 
contradiction with the background of code intended by author/producer/interior designer due to semiotic process. Creative process of reinterpreting Pracimayasa interior as the royal guest welcoming place in the attempt of enlivening traditional custom and etiquette of welcoming royal guest as one of Javanese culture's greatnesses, in turn is conceived by tourists as the tour prestige place, photo booth filling in social media, and reinforcing consumerism culture rather than conserving the royal guest welcoming tradition.

\section{REFERENCES}

[1] Adian, Doni Garhal, (2002). Menabur Kuasa Menuai Wacana. Majalah Basis. No. 01-02 Tahun ke 51 Januari Pebruari 2002, pp.42-49.

[2] Ardhiati, Yuke. (2005). Bung Karno Sang Arsitek: Kajian Artistik Karya Arsitektur, Tata Ruang Kota, Interior, Simbol, Mode Busana dan Teks Pidato 1926-1945. Jakarta: Komunitas Bambu.

[3] Ave, Job. (1991). Keraton of Java the Research and Publication of This Manuscript Were Founded. American: Express Foundation.

[4] Kuntawijaya. (2004). Raja, Priyayi, dan Kawula. Jogyakarta: Ombak.

[5] Lechte, John. (2001). Fity Key Contemprerr Thinkers Form Strukturalism to Postmodernity. London: Routledge.

[6] Lubis, Akhyar Yusuf. (2004). Setelah Kebenaran dan Kepastian dihancurkan Masih Adakah Tempat Berpijak Bagi Ilmuwan: Sebuah Uraian Filsafat Ilmu Pengetahuan Kaum Posmodernis. Bogor: Akademika
[7] Marrota, A., Spallone, R., Lo Turco, M., Zich, U. Vitalli, M., Marchis, E. \& Pavignano, M. (2017). Visual Images and Language in Architecture: Signifier Semiotics and Meaning Semiotics. Proceedings, IMAGINI?. MDPI. Retrieved from: www.mdpi.com/2504-3900/1/9/964/pdf

[8] Piliang, Yasraf Amir. (2003). Tafsir Cultural Studies Atas Matinya Makna. Bandung: Jalasutra

[9] Pitana, Titis Srimuda. (2006). Estetika Arsitektur Jawa: Religiusitas Bentuk dan Ruang. Dharmastri Jurnal Ilmu Agama dan Kebudayaan

[10] Ramzy, Nelly Shafik. (2013). Visual language in Mamluk architecture: A semiotic analysis of the Funerary Complex of Sultan Qaitbay in Cairo. Frontiers of Architectural Research. 2 (3), September 2014, pp. 338-353. Retrieved from: https://www.sciencedirect.com/science/article/pii/S20952635 13000289

[11] Ritzer, George. (2004). Teori Sosial Postmodern. Yogyakarta: Kreasi Wacana

[12] Sorgdrager, P. (1989). Gesprekken Met Den Pangeran/ Percakapan dengan Pangeran-Adat Istiadat Pada Tahun 1901 Zaman Pemerintahan Sunan Paku Buwana X Dan Kanjeng Gusti Mangkunegoro VI- No: 7; MS Mangkunegaran No. 1397

[13] Suseno, Magnis-Franz. (1996). Etika Jawa-Sebuah Analisa Falsafi tentang Kebijaksanaan Hidup Jawa. Jakarta: PT Gramedia Pustaka Utama

[14] Scoppert, Peter \& Damais, Soedarmadji. (1997). Java Style. Singapore: Editions Didier Millet

[15] Broadbent, G., Bunt, R., and Jencks, C. (1980). Sign, Symbols, and Architecture. New York: John Wiley \& Sons Ltd. 